\title{
(RETRACTED) Pengaruh Pemberian Model Latihan Isometrik Terhadap Kadar Glukosa Darah Pada Mencit (Mus Musculus) Diabetes Mellitus
}

\author{
Sonia Hadiyanti ${ }^{1}$ Harmayetty $^{2}$, Ika Yuni Widyawati ${ }^{3}$ \\ ${ }^{1}$ Jurusan Keperawatan/Poltekkes Kemenkes Mataram/Indonesia \\ ${ }^{2,3}$ Fakultas Keperawatan/ Universitas Airlangga/Indonesia
}

\begin{abstract}
Abstrak
THIS ARTICLE IS RETRACTED DUE TO REDUNDANT PUBLICATION. Berdasarkan penelitian terbaru, olahraga/ latihan mempunyai efek yang signifikan dalam menurunkan glukosa darah penelitian ini bertujuan untuk mengidentifikasi efek dari model latihan isometrik terhadap kadar glukosa darah pada mencit yang dikondisikan mengalami diabetes mellitus. Penelitian ini adalah penelitian eksperimen murni (True Experiment). Menggunakan rancangan eksperimen The Randomise Post Test Only Control Group Design. Sampel adalah mencit jantan dengan berat 20-27 gram. 27 ekor mencit jantan dibagi menjadi tiga kelompok yaitu kelompok control terdiri dari mencit normal yang diinjeksi $\mathrm{NaCl}$ sebagai placebo. Kelompok kedua adalah mencit diabetes yang tidak diberikan latihan isometrik dan kelompok ketiga adalah mencit diabetes diberikan latihan isometrik. Kelompok kedua dan ketiga diinjeksi streptozotocin (STZ) untuk meginduksi DM. Setelah 48 jam diinjeksi, kedua kelompok diberikan glukosa oral (Dextrose-40\%). Kelompok ketiga diberikan latihan isometrik menggunakan treadmill selama 23.31 menit dengan kecepatan $21 \mathrm{~cm} /$ detik dan sudut elevasi $0^{\circ}$. Data dianalisa menggunakan One Kolmogorov-Smirnov test, ANOVA test dan Least Significance Difference (LSD) dengan $\alpha<0.05$. Analisa One Kolmogorov-Smirnov test $p=0.94$ pada kelompok kontrol, $\mathrm{p}=0.50$ pada kelompok mencit diabetes, and $\mathrm{p}=0.19$ pada kelompok perlakuan. Hasil ANOVA tes adalah $\mathrm{p}=0.08$. Hasil LSD untuk gluksa darah adalah $\mathrm{p}=0.23$ untuk kelompok perlakuan. Hal ini mungkin terjadi karena pada kelompok kedua terdapat 2 mencit dengan glukosa darah normal dan pada kelompok ketiga kadar glukosa darah awal tidak diketahui. Sehingga, mungkin saja kelompok tersebut juga memiliki kadar glukosa darah normal. Dapat disimpulkan bahwa tidak ada efek latihan isometrik dalam menurunkan kadar glukosa darah. Penelitian selanjutnya disarankan mengidentifikasi lebih jauh tentang frekuensi dan intensitas latihan isometrik yang dapat mempengaruhi penurunan kadar glukosa darah.
\end{abstract}

Keyword: Latihan Isometrik, Kadar Glukosa Dara, Diabetes Mellitus, Mencit

\section{The Effect Of Isometric Exercise Model On Blood Glucose In Diabetic Mice (Musmusculus) Abstract}

Based on the latest research, exercise had significant effect to decrease blood glucose. The aimed of this study was to investigate the effect of isometric exercise model on blood glucose in Diabetic Mice (Mus musculus). This research was used a true experimental study with the randomize post-test only control group design. The sample was male mice (Mus musculus) in 20-27 grams weight. 27 male mice were divided into three groups; the first group was normal group (control) that injected by $\mathrm{NaCl}$ as placebo, the second group was diabetic mice and the third group was diabetic mice with exercise. Both second group and third group were injected by streptozotocin (STZ) to induce Diabetes Mellitus. After 48 hours injected, all groups were given oral glucose (Dextrose-40\% or D40). One hour after they given by D40, the third group was treated by isometric exercise used treadmill for 23.31 minutes with $21 \mathrm{~cm} /$ second speed and $0^{\circ}$ elevation angle. Then the blood samples of all groups were taken to measure the blood glucose level. Data were analyzed by One Kolmogorov- 
Smirnov test, ANOVA test, and Least Significance Difference (LSD) with significance level of $\alpha<0.05$. The result of One Kolmogorov-Smirnov test were $p=0.94$ in normal group, $p=0.50$ in diabetic group, and $\mathrm{p}=0.19$ in diabetic with exercise group. The result of ANOVA test was $\mathrm{p}=0.08$. The result of LSD for blood glucose revealed was $\mathrm{p}=0.23$ for diabetic group and diabetic with exercise group. The researcher had an assumption that probably it happened because of in second group there were two mice that had normal blood glucose levels and in the third group the initial blood glucose levels were unknown, hence they probably could had normal blood glucose levels too. It can be concluded that there is no effect of isometric exercise to decrease blood glucose. Further research should investigate more about the frequency and intensity of isometric exercise that could has effect to decrease blood glucose.

Keyword: Isometric exercise, blood glucose level, Diabetes mellitus, mice

\section{PENDAHULUAN}

Diabetes Mellitus (DM) merupakan suatu kelompok penyakit metabolik dengan karakteristik hiperglikemia yang terjadi karena kelainan sekresi insulin, kerja insulin atau keduanya (American Diabetes Association, 2010). Menurut data WHO pada tahun 2000 jumlah pasien DM di dunia (di atas umur 20 tahun) berjumlah 150 juta orang dengan perkiraan pada tahun 2025 akan menjadi 300 juta orang. International Diabetic Federation (IDF) tahun 2007, mengestimasi bahwa jumlah penduduk Indonesia usia 20 tahun ke atas menderita DM sebanyak 5,6 juta orang pada tahun 2001 dan angka tersebut akan meningkat menjadi 8,2 juta pada tahun 2020. Ancaman DM terus membayangi kehidupan masyarakat. Selain kematian, DM juga menyebabkan kecacatan. Sebanyak 30\% penderita DM mengalami kebutaan akibat komplikasi retinopati dan 10\% harus menjalani amputasi tungkai kaki.

Pengelolaan Diabetes Mellitus terdiri dari 5 pilar utama yaitu perencanaan diet, latihan jasmani, terapi medis, edukasi dan pemantauan gula darah (Smeltzer \& Bare, 2008). Hasil penelitian yang dilakukan oleh Nadimin (2009) menunjukan bahwa diet tinggi serat dapat menurunkan kadar glukosa darah sewaktu (GDS) sebanyak $107 \mathrm{mg} / \mathrm{dl}$, dari $344 \mathrm{mg} / \mathrm{dl}$ menjadi $237 \mathrm{mg} / \mathrm{dl}$ dan pada glukosa darah puasa menurunkan $82,8 \mathrm{mg} / \mathrm{dl}$ dari kadar glukosa puasa awal 225,7 mg/dl menjadi $142,9 \mathrm{mg} / \mathrm{dl}$. Penelitian lain menunjukkan bahwa latihan fisik senam aerobik dapat menurunkan kadar glukosa darah rerata $235 \mathrm{mg} / \mathrm{dl}$ menjadi 223,14 mg/dl (Indriyani, 2007). Berdasarkan hasil penelitian yang dilakukan Yoga (2011) bahwa diet, latihan fisik dan terapi farmakologis memiliki efek dalam menurunkan kadar glukosa darah, oleh sebab itu ketiganya tidak dapat dipisahkan satu sama lain dalam pengelolaan DM.

Menurut Soegondo dalam Indriyani (2007) latihan fisik pada penderita DM memiliki peranan yang sangat penting dalam mengendalikan kadar gula dalam darah, dimana saat melakukan latihan fisik terjadi peningkatan pemakaian glukosa oleh otot yang aktif sehingga secara langsung dapat menyebabkan penurunan glukosa darah. Latihan fisik adalah stimulus yang kuat terhadap masuknya 
glukosa ke dalam otot skeletal. Sejauh ini penelitian tentang pengaruh latihan terhadap kadar glukosa darah telah dilakukan, namun sampai saat ini model latihan isometrik yang dapat digunakan sebagai metode terapi DM untuk membantu meregulasi kadar glukosa darah belum dapat dijelaskan.

Pada penderita DM mengalami resistensi insulin atau defisiensi insulin yang diakibatkan oleh kerusakan sel $\beta$ pankreas. Kekurangan insulin dapat menyebabkan terjadinya sedikit atau tidak ada ikatan dengan reseptor sehingga proses translokasi transporter glukosa (GLUT-4) ke membran sel menjadi terhambat. GLUT-4 memfasilitasi masuknya glukosa ke dalam sel. Bila proses translokasi GLUT-4 terganggu akan menyebabkan ambilan glukosa dalam darah menjadi terganggu, sehingga terjadi penumpukan glukosa di ekstrasel yang akan mengakibatkan glukosa darah meningkat atau disebut juga hiperglikemia (Ganong, 2008). Latihan fisik akan meningkatkan transportasi glukosa dengan cara menstimulasi translokasi GLUT-4 ke permukaan sel otot. Pada saat kontraksi terjadi peningkatan pemakaian energi sehingga terjadi penurunan Adenosine Triphosphate (ATP). ATP akan dipecah menjadi cyclic Adenosine Monophosphate (cAMP) oleh enzim Adenosine Monophosphate Kinase (AMPK), hal ini menyebabkan perubahan metabolik termasuk transport glukosa (Sigal, 2004). Kontraksi otot pada latihan isometrik akan mengakibatkan peningkatan kalsium (Ca2+) di sitosol yang akan mengaktifkan enzim Calmodulin Dependent Protein Kinase (CaMK II). Enzim CaMK II dan AMPK akan menstimulasi translokasi GLUT-4 ke permukaan membran sel yang selanjutnya akan membawa glukosa masuk ke dalam sel dan terjadi penurunan glukosa darah (Rose, 2005).

Berdasarkan uraian di atas, peneliti ingin meneliti pengaruh model latihan isometrik terhadap kadar glukosa darah pada mencit yang dikondisikan mengalami diabetes mellitus. Kontraksi otot isomerik adalah suatu kontraksi otot dimana tidak terjadi perubahan panjang otot dengan beban dapat berubah-ubah (Marieb, 2007). Latihan isometrik sangat bermanfaat dilakukan pada kondisi tertentu yaitu pada saat tidak diinginkan adanya suatu gerakan.

\section{METODE}

Penelitian ini merupakan penelitian eksperimen murni (True Experiment). Menggunakan rancangan eksperimen The Randomise Post Test Only Control Group Design. Populasi dalam penelitian ini adalah mencit (Mus musculus) yang berada di ruang pemeliharaan hewan coba. Sampel dipilih berdasarkan kriteria sebagai berikut: Mencit berjenis kelamin jantan, sehat, berusia 8-12 minggu dengan berat badan antara 20-25 gram. Jumlah sampel yaitu 27 ekor mencit yang dibagi kedalam tiga kelompok yaitu kelompok kontrol (mencit tanpa DM), kelompok mencit DM yang diberi perlakuan (model latihan isometric) dan kelompok mencit DM yang tidak diberi perlakuan. Masingmasing kelompok sampel terdiri dari 9 orang mencit.

Variabel bebas dalam penelitian ini adalah model latihan isometric. Variabel terikat adalah kadar glukosa darah mencit (Mus musculus) Diabetes Mellitus setelah diberikan model latihan isometrik.Variabel kendali (kontrol) adalah jangka waktu pemberian latihan isometrik yaitu 23,31 
menit, kecepatan treadmill $21 \mathrm{~cm} /$ detik, sudut elevasi treadmill $0^{\circ}$ (tanpa inklinasi), dosis glukosa oral ( $2 \mathrm{mg} / \mathrm{g}$ bb mencit per pemberian) dan waktu pemberian glukosa oral 60 menit sebelum latihan.

Instrumen yang digunakan dalam penelitian ini adalah spectrophotometer untuk mengetahui nilai glukosa darah. Studi pendahuluan dilakukan untuk menetapkan protokol pelaksanaan latihan yang akan diberikan pada sampel (mencit). Berdasarkan hasil uji 3 pilihan kecepatan, kecepatan terbaik yang dapat ditempuh mencit untuk berlari adalah kecepatan $21 \mathrm{~cm} /$ detik. Peneliti juga menetapkan lama atau dosis pemberian latihan. Peneliti mendapatkan kecepatan maksimal pada mencit yaitu 33,31 menit. Untuk menetapkan sebagai latihan aerobik, kecepatan maksimal yang telah diperoleh, dikalikan 70\% VOmax, (sesuai dengan rumus latihan tipe aerobik) sehingga peneliti mendapatkan hasil kecepatan 23,31 menit. Berdasarkan hasil studi pendahuluan ini peneliti menetapkan latihan model isometrik (dengan menggunakan treadmill) yang diberikan pada mencit dalam penelitian ini adalah berlari dengan sudut $0^{\circ}$ dan kecepatan $21 \mathrm{~cm} /$ detik selama 23,31 menit.

Peneliti melakukan alokasi random pada mencit menjadi 2 kelompok yaitu kelompok 1 (9 ekor mencit) yang merupakan kelompok mencit normal dan tidak diberikan intervensi. Kelompok 2 (18 ekor mencit) yang akan diinjeksi streptozotocin (STZ) sebagai penginduksi Diabetes Mellitus (DM). Kelompok 2 diinjeksi STZ dengan dosis $3 \mathrm{mg} / 20 \mathrm{gr}$ bb yang dilarutkan dalam Na-sitrat, hingga mencapai $\mathrm{pH} 4,5$. Berdasarkan prosedur tetap, mencit dipuasakan selama 4 jam sebelum diinjeksi STZ. (Brosius, 2009). STZ disuntikan melalui intraperitonial dengan posisi kepala mencit searah gravitasi bumi. 48 jam paska penyuntikan STZ, peneliti kembali melakukan alokasi random pada kelompok 2. Mencit pada kelompok 2 dibagi menjadi dua kelompok yaitu menjadi kelompok 2 dan 3 , masing-masing kelompok terdiri dari 9 ekor mencit. Kelompok 2 adalah kelompok mencit yang telah menjadi DM dan tidak diberikan intervensi, sedangkan kelompok 3 adalah kelompok mencit yang telah menjadi DM dan diberi intervensi berupa latihan isometrik.

Seluruh mencit pada ketiga kelompok diberi glukosa oral (Dextrose-40\% atau D40) dengan dosis $2 \mathrm{mg} / \mathrm{gr}$ bb mencit (Zhang, 2011). Berat badan mencit setelah disuntik STZ akan turun sekitar 10-12\% (Purwanto, 2012), sehingga untuk dosis glukosa oral, peneliti tidak melakukan penimbangan ulang. Dosis D40 yang diberikan adalah $0,1 \mathrm{ml}$ dilarutkan dalam $0,4 \mathrm{ml} \mathrm{NaCl}$. Satu jam setelah diberikan glukosa oral, mencit pada kelompok 1 dan 2 dibiarkan menjalankan aktivitas di dalam kandang seperti biasa, sedangkan mencit pada kelompok 3 diberikan latihan isometrik dengan menggunakan treadmill dengan kecepatan $21 \mathrm{~cm} /$ detik selama 23,31 menit dan sudut elevasi 00 . Latihan yang diberikan bersifat akut, yaitu hanya dilakukan satu kali untuk melihat efek jangka pendek latihan.

Pengambilan sampel darah mencit pada ketiga kelompok dilakukan setelah pemberian latihan pada mencit kelompok 3 selesai. Sampel darah mencit yang diambil di intrakardial sebanyak 0,2 ml kemudian dilakukan pengukuran kadar glukosa darah menggunakan spectrophotometer yang telah dikalibrasi. Data kadar glukosa darah yang telah diperoleh kemudian dianalisa secara statistik. uji 
normalitas data dengan One-Sample Kolmogorov-Smirnov Test. Selanjutnya dilakukan uji One-way ANOVA untuk uji kuantitatif dengan nilai $\alpha=0,05$ karena data terdistribusi normal.

\section{HASIL PENELITIAN}

1. Hasil observasi berat badan dan kadar glukosa darah mencit paska pemberian glukosa oral

\section{kelompok 1}

Tabel 1. Hasil observasi berat badan dan kadar glukosa darah mencit paska pemberian glukosa oral pada kelompok 1

\begin{tabular}{ccc}
\hline No & BB mencit (gram) & Kadar glukosa darah mencit (mg/dl) \\
\hline 1 & 24 & 146,64 \\
2 & 22 & 75,46 \\
3 & 25 & 165,00 \\
4 & 23 & 67,85 \\
5 & 20 & 109,49 \\
6 & 22 & 132,32 \\
7 & 24 & 178,88 \\
8 & 21 & 133,66 \\
9 & 22 & 173,51 \\
\hline Uji One-Sample & Rerata $=22,5$ & Rerata $=131,42$ \\
Kolmogorov- & $\mathrm{p}=0,89$ & $\mathrm{p}=0,94$ \\
Smirnov Test & & \\
\hline
\end{tabular}

Berdasarkan tabel 1 di atas didapatkan rerata berat badan dari 9 ekor mencit adalah 22,55 gram dengan nilai $\mathrm{p}=0,89$. Berdasarkan nilai $\mathrm{p}$, hasill uji statistik menunjukkan bahwa data berat badan mencit pada kelompok 1 berdistribusi normal. Rerata kadar glukosa darah paska pemberian glukosa oral didapatkan $131,42 \mathrm{mg} / \mathrm{dl}$ dengan nilai $\mathrm{p}=0,94$. Berdasarkan nilai $\mathrm{p}$, hasil uji statistik menunjukkan bahwa data kadar glukosa darah mencit paska pemberian glukosa oral pada kelompok 1 berdistribusi normal.

2. Hasil observasi berat badan dan kadar glukosa darah mencit paska pemberian glukosa oral pada kelompok 2

Tabel 2 Hasil observasi berat badan dan kadar glukosa darah mencit paska pemberian glukosa oral pada kelompok 2

\begin{tabular}{ccc}
\hline No & BB mencit (gram) & Kadar glukosa darah mencit $(\mathrm{mg} / \mathrm{dl})$ \\
\hline 1 & 23 & 335,13 \\
2 & 22 & 204,40 \\
3 & 24 & 120,00 \\
4 & 23 & 111,72 \\
5 & 21 & 391,54 \\
6 & 22 & 155,60 \\
7 & 25 & 141,27
\end{tabular}




\begin{tabular}{ccc}
8 & 22 & 548,23 \\
9 & 22 & 201,71 \\
\hline Uji One-Sample & Rerata $=22,6$ & Rerata $=245,51$ \\
\cline { 2 - 3 } Kolmogorov- & $\mathrm{p}=0,56$ & $\mathrm{p}=0,50$ \\
Smirnov Test & & \\
\hline
\end{tabular}

Berdasarkan tabel 2 di atas didapatkan rerata berat badan 9 ekor mencit adalah 22,6 gram, dengan nilai $\mathrm{p}=0,56$. Berdasarkan nilai $\mathrm{p}$ tersebut, hasil uji statistik menunjukkan bahwa data berat badan kelompok 2 berdistribusi normal. Rerata kadar glukosa darah paska pemberian glukosa oral didapatkan 245,51 mg/dl dengan nilai $\mathrm{p}=0,50$. Berdasarkan nilai $\mathrm{p}$ tersebut, hasil uji statistik menunjukkan bahwa data kadar glukosa darah mencit pada kelompok 2 berdistribusi normal.

\section{Hasil observasi berat badan dan kadar glukosa darah mencit paska pemberian glukosa oral} pada kelompok 3

Tabel 3 Hasil observasi berat badan dan kadar glukosa darah mencit paska pemberian glukosa oral pada kelompok 3

\begin{tabular}{ccc}
\hline No & BB mencit (gram) & Kadar glukosa darah mencit (mg/dl) \\
\hline 1 & 22 & 122,00 \\
2 & 21 & 126,95 \\
3 & 21 & 150,67 \\
4 & 25 & 128,74 \\
5 & 23 & 165,45 \\
6 & 22 & 134,11 \\
7 & 21 & 142,17 \\
8 & 26 & 335,13 \\
9 & 23 & 362,88 \\
\hline Uji One-Sample & Rerata $=22,66$ & $\mathrm{p}=0,19$ \\
Kolmogorov- & $\mathrm{p}=0,84$ & \\
Smirnov Test & & \\
& & \\
\hline
\end{tabular}

Dari tabel 3 di atas didapatkan rerata berat badan dari 9 ekor mencit sebesar 22,66 gram dengan nilai $\mathrm{p}=0,84$. Berdasarkan nilai $\mathrm{p}$, hasil uji statistik menunjukkan bahwa data berat badan mencit pada kelompok 3 berdistribusi normal. Rerata kadar glukosa darah paska pemberian glukosa oral sebesar 185,34 mg/dl dengan nilai $\mathrm{p}=0,19$. Berdasarkan nilai $\mathrm{p}$, hasil uji statistik menunjukkan bahwa data kadar glukosa darah pada kelompok 3 berdistribusi normal.

4. Hasil anasilis statistik kadar glukosa darah antara kelompok 1,2 dan 3

Uji homogenitas dengan One way Anova Homogenity of Variance dilakukan pada kadar glukosa darah paska pemberian glukosa oral. 
Tabel 4 Hasil anasilis statistik kadar glukosa darah antara kelompok 1,2 dan 3

\begin{tabular}{lccc}
\hline \multirow{2}{*}{\multicolumn{1}{c}{ Keterangan }} & \multicolumn{3}{c}{ Kelompok } \\
\cline { 2 - 4 } & Kel.1 (kontrol) & Kel.2 (DM) & Kel.3 (DM) \\
\hline Rerata (mean) & 131,42 & 245,51 & 185,34 \\
Standar Deviasi & 40,37 & 148.83 & 93.98 \\
Signifikansi (p) & & 0,08 & \\
\hline
\end{tabular}

Berdasarkan tabel 4 hasil uji statistik One Way Anova menunjukkan bahwa kadar glukosa darah paska pemberian glukosa oral memiliki nilai $\mathrm{p}=0,08$. Nilai $\mathrm{p}$ tersebut menunjukkan bahwa tidak terdapat perbedaan yang bermakna untuk rerata kadar glukosa darah pada keseluruhan kelompok.

5. Hasil analisis statistik dengan menggunakan Post Hoc Test-LSD

Tabel 5. Hasil analisis statistik menggunakan Post Hoc Test-LSD

\begin{tabular}{llccc}
\hline \multicolumn{2}{c}{ Kelompok } & Rerata (I-J) & Signifikan \\
\cline { 1 - 2 } \multicolumn{1}{c}{ Kelompok (I) } & Kelompok (J) & & \\
\hline Kontrol & DM & $-114.08820^{*}$ & .029 \\
& DM dan latihan & -53.92072 & .284 \\
DM & kontrol & $114.08820^{*}$ & .029 \\
& DM dan latihan & 60.16748 & .233 \\
DM dan latihan & kontrol & 53.92072 & .284 \\
& DM & -60.16748 & .233 \\
\hline
\end{tabular}

Berdasarkan tabel 5. di atas dapat diketahui perbandingan pasangan rerata kelompok percobaan. Perbandingan rerata kelompok 1 dengan kelompok 2 memiliki nilai $\mathrm{p}=0,02$ yang berarti bahwa ada perbedaan bermakna pada nilai kadar glukosa darah paska pemberian glukosa oral antara kelompok 1 dan kelompok 2. Perbandingan rerata kelompok 1 dengan kelompok 3 memiliki nilai $\mathrm{p}=0,28$ yang berarti bahwa tidak ada perbedaan pada nilai kadar glukosa darah paska pemberian glukosa oral antara kelompok 1 dan kelompok 3. Perbandingan rerata kelompok 2 dengan kelompok 3 memiliki nilai $\mathrm{p}=0,23$ yang berarti bahwa tidak ada perbedaan yang bermakna pada nilai kadar glukosa darah paska pemberian glukosa oral antara kelompok 2 dan kelompok 3.

\section{PEMBAHASAN}

Kadar glukosa darah mencit paska pemberian glukosa oral pada kelompok 1 didapatkan hasil yang bervariasi antara 67,85 sampai dengan 178,87 mg/dl. Dalam penelitian ini kadar glukosa darah pada kelompok 1 dijadikan acuan sebagai kadar glukosa darah normal. Secara fisiologis setelah pemberian glukosa, kadar glukosa darah meningkat dan mencapai 
puncaknya pada waktu 1 jam, kemudian turun ke kadar 2 jam. Dalam keadaan fisiologis, insulin disekresikan sesuai dengan kebutuhan tubuh normal oleh sel beta. Sekresi insulin normal akan terjadi setelah adanya rangsangan seperti glukosa yang berasal dari makanan atau minuman. Insulin yang dihasilkan ini, berfungsi mengatur regulasi glukosa darah agar selalu dalam batas-batas fisiologis, baik saat puasa maupun setelah mendapat beban.

Sekresi insulin berfungsi untuk menjaga kadar glukosa darah selalu dalam batas-batas normal, sebagai cerminan metabolisme glukosa yang fisiologis (Sherwood, 2011). Rendahnya sensitivitas atau tingginya resistensi jaringan tubuh terhadap insulin dapat mempengaruri metabolisme glukosa pada tubuh. Selain itu regulasi glukosa darah tidak hanya berkaitan dengan metabolisme glukosa di jaringan perifer, tapi juga di jaringan hepar dimana GLUT-2 berfungsi sebagai kendaraan pengangkut glukosa melewati membran sel kedalam sel. Dalam hal ini jaringan hepar ikut berperan dalam mengatur homeostasis glukosa tubuh (Weyer, 2000).

Berdasarkan hasil analisis statistik kadar glukosa darah pada kelompok 1 memiliki rentang cukup jauh yaitu sebesar 40,37 (dilihat dari standar deviasi). Peneliti berasumsi bahwa rentang yang cukup jauh pada kadar glukosa darah mencit paska pemberian glukosa oral pada kelompok 1 dapat disebabkan oleh sensitivitas dan resistensi terhadap insulin yang berbeda-beda pada setiap mencit.

Hasil pengukuran kadar glukosa darah pada kelompok 2 didapatkan bahwa 2 ekor mencit berkisar antara 111,72-120,40 mg/dl, sedangkan 7 ekor mencit lainnya pada pengukuran kadar glukosa darah menunjukkan nilai yaitu antara 141,27-548,23 mg/dl. Kadar glukosa darah pada kelompok 2 dijadikan acuan sebagai kadar glukosa darah paska pemberian glukosa oral pada mencit yang mengalami Diabetes Mellitus (DM).

Berdasarkan teori dari Szkudelski (2001) disebutkan bahwa streptozotocin (STZ) bekerja dengan menghasilkan Nitrit oxide (NO) dan oksigen reaktif yang merusak pankreas sehingga tidak dapat menghasilkan insulin dengan normal dan menyebabkan kadar glukosa darah tinggi. Dampak STZ sendiri sesuai standar operasional prosedur penyuntikan STZ oleh Animal Models of Diabetic Complications Consortium (2003), akan terllihat pada 2 hari hingga 4 minggu setelah penyuntikan. Pada penelitian ini pengambilan sampel darah dilakukan pada 48 jam setelah penyuntikan yang merupakan batas minimal terlihatnya dampak dari STZ.

Pada DM tipe 1 terjadi kerusakan pankreas sehingga tidak dapat atau kurang mampu memproduksi insulin. Ketidakmampuan untuk menghasilkan insulin menyebabkan glukosa menjadi menumpuk di dalam peredaran darah karena tidak dapat diangkut ke dalam sel. Hal ini menyebabkan peningkatan kadar glukosa darah di dalam sel (Smeltzer \& Bare, 2002)

Peneliti berasumsi bahwa kadar glukosa darah 2 ekor mencit yang masih berada dibawah rerata kadar glukosa darah mencit normal dapat disebabkan oleh STZ yang disuntikkan belum memberikan dampak secara maksimal pada hari ke-2. Terdapat peningkatan kadar glukosa yang sangat signifikan pada 3 mencit yang mencapai nilai 353,16 mg/dl, 391,54 mg/dl dan 548,23 mg/dl hal ini dapat disebabkan oleh kerusakan pankreas pada mencit akibat suntikan STZ. Kerusakan pankreas 
yang terjadi menyebabkan produksi insulin berkurang sehingga kadar glukosa darah meningkat. Peneliti berasumsi bahwa perbedaan kadar glukosa darah yang berbeda-beda pada tiap mencit pada kelompok 2 dapat juga dikarenakan faktor genetik dan respons fisiologis tiap mencit yang berbedabeda dalam beradaptasi terhadap suntikan STZ. Kedua faktor tersebut belum dapat dikendalikan oleh peneliti, sehingga perlu dibuktikan lebih lanjut pengaruh faktor genetik dan respons fisiologis mencit terhadap kadar glukosa darah.

Hasil pengukuran kadar glukosa darah pada kelompok 3 didapatkan bahwa 7 ekor mencit berada pada rentang kadar glukosa darah normal yaitu 122,00-165,45 mg/dl. Hal ini sesuai dengan pendapat Warren (2000) bahwa peningkatan aliran darah ke otot selama latihan dapat meningkatkan distribusi insulin ke otot sehingga memicu masuknya glukosa ke dalam otot pada fase akut. Latihan juga meningkatkan jumlah reseptor insulin dan jumlah aktivitas intrinsik dari glukosa transporter menuju membran plasma sel otot. Dua mencit lainnya pada kelompok 3 memiliki kadar glukosa darah sebesar 335,13 mg/dl dan 362,88 mg/dl yang masih di atas kadar glukosa darah normal. Kondisi ini dapat terjadi dikarenakan adanya kemampuan tubuh dalam menanggapi stres yang diberikan berbedabeda pada mencit dimana menurut pendapat Sugiharto (2003) disebutkan bahwa latihan fisik sebaiknya dilakukan sesuai dengan kemampuan tubuh dalam menanggapi stres yang diberikan, bila tubuh diberi beban latihan yang terlalu ringan maka tidak akan terjadi proses adaptasi sehingga kadar glukosa darah tidak mengalami penurunan signifikan.

Mekanisme kerja latihan isometrik terhadap penurunan kadar glukosa darah pada Diabetes Mellitus (DM) dimulai ketika penderita DM mengalami resistensi insulin atau defisiensi insulin yang diakibatkan oleh kerusakan sel $\beta$ pankreas. Kekurangan insulin dapat menyebabkan terjadinya sedikit atau tidak ada ikatan dengan reseptor sehingga proses translokasi transporter glukosa 4 (GLUT-4) ke membran sel menjadi terhambat. GLUT-4 memfasilitasi masuknya glukosa ke dalam sel. Bila proses translokasi GLUT-4 terganggu akan menyebabkan ambilan glukosa dalam darah menjadi terganggu, sehingga terjadi penumpukan glukosa di ekstrasel yang akan mengakibatkan glukosa darah meningkat atau disebut juga hiperglikemia (Ganong, 2008)

Penggunaan treadmill tanpa inklinasi, akan menimbulkan suatu kontraksi isometrik. Pada latihan isometrik terjadi suatu kontraksi yang akan menyebabkan retikulum sarkoplasma (SR) melepaskan sejumlah ion kalsium (Ca2+) di sitosol. Ca2+ di sitosol akan mengaktifkan enzim Calmodulin Dependent Protein Kinase (CaMK II) yang akan merangsang translokasi GLUT-4 (Guyton \& Hall, 2007). Pada latihan isometrik dibutuhkan energi untuk melakukan kontraksi. Kontrakasi otot terus berlangsung menyebabkan peningkatan pemakaian energi sehingga terjadi penurunan Adenosine Triphosphate (ATP). ATP akan dipecah menjadi cyclic Adenosine Monophosphate (cAMP) oleh enzim Adenosine Monophosphate Kinase (AMPK). Enzim CaMK II dan AMPK memiliki fungsi yang sama yaitu mentranslokasi GLUT-4 di otot yang berfungsi memfasilitasi ambilan glukosa masuk ke dalam sel shingga terjadi penurunan glukosa darah (Rose, 2005). 
Ketika tubuh melakukan latihan fisik yang merupakan salah satu bentuk stresor fisik dapat menyebabkan gangguan homeostatis, maka tubuh akan memberi tanggapan berupa mekanisme umpan balik negatif. Tanggapan tersebut berupa responss 'jawaban sewaktu' adalah perubahan fungsi organ tubuh yang sifatnya sementara dan berlangsung tiba-tiba, sebagai akibat dari aktivitas fisik. Perubahan fungsi ini akan hilang dengan segera dan kembali normal setelah aktivitas dihentikan dalam jangka waktu tertentu. Tanggapan lainnya disebut adaptasi 'jawaban lambat' adalah perubahan struktur atau fungsi organ-organ tubuh yang sifatnya lebih menetap karena latihan fisik yang dilakukan dengan teratur dalam periode waktu tertentu. Reaksi adaptasi hanya akan timbul apabila beban latihan yang diberikan intensitasnya cukup memadai dan berlangsung cukup lama (Sugiharto, 2000).

Ada dua istilah latihan yaitu acute exercise (latihan yang bersifat akut) dan chronic exercise (latihan yang bersifat kronik). Acute exercise adalah latihan yang dilakukan hanya sekali saja atau disebut juga dengan exercise, sedangkan chronic exercise adalah latihan yang dilakukan berulangulang sampai beberapa hari atau sampai beberapa bulan (training) (Harsono di dalam McArdle, 2001). Hal penting yang perlu diperhatikan ialah dengan melakukan training akan terjadi perubahan penting di dalam tubuh sedangkan dengan melakukan exercise perubahan yang terjadi kurang penting. Perubahan yang terjadi pada waktu seseorang melakukan exercise disebut dengan respons. Sedangkan perubahan yang terjadi karena training disebut adaptasi (Supriadi, 2000). Sebuah latihan yang dilakukan secara akut dapat meningkatkan GLUT4 mRNA pada otot tikus. AMP-activated protein kinase (AMPK) akan aktif dan meningkat diotot rangka pada latihan yang dilakukan secara rutin (Burton, 2004). Berdasarkan pendapat tersebut, maka penelitian ini dilakukan dengan memberikan acute exercise sehingga pendapat tersebut menjelaskan kemungkinan kurang efektifnya latihan pada beberapa mencit.

\section{KESIMPULAN}

Berdasarkan hasil penelitian dapat disimpulkan bahwa pemberian model latihan isometrik tidak dapat menurukan kadar glukosa darah pada mencit Diabetes Mellitus. Penelitian selanjutnya diharapkan menggunakan desain penelitian pre-post control group design dengan jumlah sampel 27 ekor mencit untuk mengetahui kadar glukosa darah awal sebelum dan sesudah perlakuan latihan isometrik dengan lama latihan 23,3 menit, kecepatan $21 \mathrm{~cm} /$ detik dan menggunakan sudut $0^{\circ}$ sehingga peneliti mengetahui nilai perubahan kadar glukosa darah. Pasca injeksi Streptozotocin (STZ) dikontrol sampai waktu maksimal agar mencit menjadi Diabetes Mellitus dan sebelum diberi perlakuan sebaiknya kadar glukosa darah mencit diukur terlebih dahulu untuk mengetahui kadar glukosa darah pasca penyuntikan Streptozotocin. Mampu meneliti frekuensi dan intensitas latihan isometrik yang tepat untuk melihat efek latihan terhadap kadar glukosa darah. 


\section{DAFTAR PUSTAKA}

American Diabates Association 2010, Clinical Practice Recommendations. Diabetes Care. http://care.diabetesjournals.org.

Ganong, W 2008, Buku Ajar Fisiologi Kedokteran, ed. 22 , EGC, Jakarta. Hal. 67-76, 347-353.

Guyton \& Hall 2007, Buku Ajar Fisiologi Kedokteran ed. 11, EGC, Jakarta. Hal. 1010-1027, 11111123.

Indriyani, P., Supriyanto, H \& Santoso, A 2007, Pengaruh Latihan Fisik: Senam Aerobik Terhadap Penurunan Kadar Gula Darah pada Penderita DM Tipe 2 di Wilayah Puskesmas Bukateja Purbalingga $\langle$ http://ejournal.undip.ac.id/index.php/medianers/article/view/717>

Marieb, EN, Hoen K 2007, Human Anatomy and Physiology, Seventh edition, Pearson Benjamin Cummings, San Fransisco. Hal. 143, 229, 284-287.

Nadimin, AS, Sadariah 2009, Pengaruh Pemberian Diit DM Tinggi Serat Terhadap Penurunan Kadar Glukosa Darah Pasien DM Tipe-2 Di RSUD Sawelangan Kabupaten Maros, Media Gizi Pangan, Vol. VII, Edisi 1, https://jurnalmediagizipangan.files.wordpress.com,

Rose, AJ \& Richter, EA 2005, Skeletal Muscle Glukosa Uptake During Exercise: How is it Regulated?, Physiology, vol. 20, hal. 260-270, http://physiologyonline.physiology.org/content/20/4/260.full.html\#ref-list-1

Szkudelski, T 2001, The Mechanism Of Alloxan And Streptozotocin Action In $\beta$ Cells Of The Rat Pancreas, Physiology Research, Hal 536-54.

Sherwood, L 2011, Fisiologi Manusia dari Sel ke Sistem, edisi 6, EGC, Jakarta. Hal. 214, 540

Sigal, RJ, Kenny, GP, Wasserman, DH \& Sceppa, CC 2004, Physical activity/Exercise and Type 2 Diabetes, Diabetes Care, vol. 27, no. 10, hal. 2518-2539, $\langle$ http://care.diabetesjournals.org/content/27/10/2518.full>, diakses 12 Maret 2012

Smeltzer, SC. \& Bare, BG 2008, Buku Ajar Keperawatan Medikal Bedah, EGC, Jakarta. Hal. 12271228

Soegondo, Soewondo, dan Subekti. 2009. Penatalaksanaan Diabetes Melitus Terpadu. Balai Penerbit UI, Jakarta. Hal. 12-13, 36-45

Sugiharto 2000, Pembentukan Radikal Bebas Oksigen dalam Aktivitas Fisik, Lab Jurnal Ilmu Keolahragaan dan Pendidikan Jasmani, 10(1): 22-32.

Yoga, AS 2011, Hubungan Antara 4 Pilar Pengelolaan Diabetes Melitus Dengan Keberhasilan Pengelolaan Diabetes Melitus Tipe 2, http://eprints.undip.ac.id, di akses tanggal 30 April 2012.

Warren, MP, Constantini NW 2000. Sport Endokrinology, Humana Press Totowa, New Jersey, USA.

Weyer C, Bogardus C, Mort DM, Tataranni PA, Pratley RE 2000. Insulin resistance and insulin secretory dysfunction are independent predictors of worsening of glucose tolerance during each stage of type 2 diabetes development. Diabetes Care 24: 89 